\title{
HOW TO MAKE DESEGREGATION WORK: THE ADAPTATION OF SCHOOLS TO THEIR NEWLY-INTEGRATED STUDENT BODIES
}

\author{
Gary ORFIELD*
}

\section{INTRODUCTION}

After a full generation of effort, most southern school systems are now desegregated, and in a number of northern and western cities the desegregation process is now beginning. The experience has shown very clearly, however, that reassignment of students is only the first step in a long process of building integrated schools. If we really believe that the schools are our most important public institution and that race is our central social problem, the difficulty in bringing about effective integration should not be surprising.

Desegregation, to be termed successful, must have eliminated widely-held racial stereotypes, broadened the cultural values transmitted by the schools, and increased the access of minority children to quality educational programs-the conduit to preferred colleges and jobs. A social revolution of this scale requires extensive adaptations within the internal processes of the school. Since schools are usually stable-often rigid-institutions, these changes are difficult to accomplish. Whenever possible, the initial desegregation plan-whether court-ordered or voluntarily drawn up by school officials - should be designed to facilitate successful adaptation within the schools.

Some of the "second generation" desegregation problems, widely publicized, have generated responses from lawyers, the courts, and civil rights officials in the Department of Health, Education, and Welfare. HEW began to impose requirements for faculty desegregation in its 1966 school desegregation guidelines. ${ }^{1}$ Many contemporary desegregation orders include provisions modeled on the Singleton case, ${ }^{2}$ which required ratios of black to white teachers in every school in a school district to reflect the ratio of black to white teachers in the school district as a whole. There has been litigation dealing with the firing of black teachers following court orders to establish a unitary school system, ${ }^{3}$

\footnotetext{
* Research Associate, Brookings Institution. This work was made possible by the opportunity the author was given to visit desegregated urban schools across the country while serving as Scholarin-Residence at the United States Commission on Civil Rights. 1972-73. Neither the Commission nor Brookings, of course, are responsible for the author's conclusions.

1. See U.S. Office of Education, Dep't of Health, Education, \& Welfare, Revised Statement of Policies for School Desegregation Plans Under Title Vi of the Civil Rights ACT of 1964 (1966).

2. See Singleton v. Jackson Municipal Separate School Dist., 419 F.2d 1211 (5th Cir.). rev'd in part. 396 U.S. $290(1970)$.

3. See Moore v. Board of Educ., 448 F.2d 709 (8th Cir. 1971): North Carolina Teachers Ass'n v. Asheboro City Bd. of Educ., 393 F.2d 736 (4th Cir. 1968); Wall v. Stanly County Bd. of Educ.. 378
} 
the use of discriminatory teacher qualification examinations, ${ }^{4}$ and other related issues. There has been litigation on the downgrading of minority administrators in desegregated school systems $s^{5}$ and on attempts to curb the practice of "push-outs" of minority students by the use of discriminatory suspension and expulsion practices. ${ }^{6}$ The assignment of disproportionate numbers of minority children to classes for the mentally retarded has been challenged ${ }^{7}$ as has the assignment of minority children to segregated lower tracks. ${ }^{8}$ Both the courts ${ }^{9}$ and $\mathrm{HEW}^{10}$ have shown increasing concern over the rights of non-English speaking children in desegregation plans, taking steps to provide opportunities for bilingual classes.

All of these issues are important, sometimes extremely important in a given school district, but they reflect an incomplete view of the desegregation process. They deal largely with the problem of who should be in a particular classroom or particular school at a given time, not with what goes on in the classroom. It is assumed that by controlling access, somehow the educational process will work out all right. Indeed, education often seems to be treated as a residual.

This essay is based on the premise that what goes on in the classroom and the nature of the educational leadership of the school are centrally important both to the success of desegregation and to the quality of education offered to all children in the system. Desegregation plans should take into account the educational changes necessary to make desegregation work. Otherwise, seem-

F.2d 275 (4th Cir. 1967), rev'g 259 F. Supp. 238 (C.D.N.C. 1966); Johnson v. Branch, 364 F.2d 177 (4th Cir. 1966).

4. See Baker v. Columbus Municipal Separate School Dist., 329 F. Supp. 706 (N.D. Miss. 1971), aff'd, 462 F.2d 1112 (5th Cir. 1972); Armstead v. Starkville Municipal Separate School Dist., 325 F. Supp. 560 (N.D. Miss. 1971), aff'd, 461 F.2d 276 (5th Cir. 1972).

5. See Singleton v. Jackson Separate School Dist., 419 F.2d 1211 (5th Cir.), rev'd in part, 396 U.S. $290(1970)$.

6. See Hawkins v. Coleman, 376 F. Supp. 1330 (N.D. Tex. 1974). Cf. Mills v. Board of Educ., 348 F. Supp. 866 (D.D.C. 1972).

7. See Larry P. v. Riles, 343 F. Supp. 1306 (N.D. Cal. 1972); Arvizu v. Waco Independent School Dist., 373 F. Supp. 1264 (W.D. Tex. 1973), rev'd in part on other grounds, 495 F.2d 499 (5th Cir. 1974). Consent decrees have been entered in several other cases challenging educationally or linguistically biased testing procedures for placing students in mentally retarded classes. See, e.g., Guadalupe Organization v. Tempe Elementary School Dist., CA 71-435 PHX (D. Ariz. Jan. 9, 1972); Diana v. California Bd. of Educ, C 7037 REP (N.D. Cal. June 18, 1971).

8. See Hobson v. Hansen, 269 F. Supp. 401 (D.D.C. 1967) (Wright, J., sitting as District Court Judge), aff'd sub nom. Smuck v. Hobson, 408 F.2d 175 (D.C. Cir. 1969); Moses v. Washington Parish School Bd., 330 F. Supp. 1340 (E.D. La. 1971), aff'd, 456 F.2d 1285 (5th Cir. 1972). See also Lemon v. Bossier Parish School Bd., 444 F.2d 1400 (5th Cir. 1971); United States v. Sunflower County School Dist., 430 F.2d 839 (1970).

9. See, e.g., Arvizu v. Waco Independent School Dist., 373 F. Supp. 1264 (W.D. Tex. 1973), revid in part, 495 F.2d 499 (5th Cir. 1974); United States v. Texas, 342 F. Supp. 24 (E.D. Tex. 1971), aff d, 466 F.2d 518 (5th Cir. 1972); Johnson v. San Francisco Unified School Dist., 339 F. Supp. 1315,1322 (N.D. Cal. 1971), vacated, 500 F.2d 349 (9th Cir. 1974).

10. For example, note the HEW proposal in United States v. Texas Educ. Agency, 467 U.S. 848, 860-6l (5th Cir. 1972), and the HEW regulation requiring school sy'stems to take remedial steps to rectify language deficiency problems. 35 Fed. Reg. 11595 (1970). 
ingly sensible goals can lead to perverse results. Under a court-ordered desegregation plan which rigidly prohibits any sort of tracking or ability grouping, a Puerto Rican high school student from a segregated ghetto school which had provided him with an abysmal mathematical background suddenly could be transferred to a school where the standards had been set by children from a white middle-class and professional neighborhood. If the receiving school complied with the prohibition against tracking and did nothing else to change either teaching methods or grading systems, the minority child who had been transferred to such a school probably would be condemned to failure-in the name of equality. This simple example illustrates the need carefully to analyze the relationship between policies articulated in desegregation plans and the actual processes of education.

Strange as it may seem, social scientists have produced little systematic, carefully controlled research on educational processes within desegregated schools. Most of the existing desegregation research merely measures achievement scores at the beginning and end of the first year of desegregation. ${ }^{11}$ And even this simple research effort is often done in a manner which, by aggregating all scores from a given school or a given grade level throughout a school system, obscures possible findings about ways the process facilitates or impedes effective integration.

Probably the best available data are contained in an evaluation of 555 southern schools that were among the last to desegregate and were studied in the early transitional phase of the process. ${ }^{12}$ This study found dramatic differences among the schools in the ways in which the desegregation process was handled. There are also a number of interesting smaller studies, including those by participant/observers who spent substantial periods of time in a single school. ${ }^{13}$ The analysis presented in this article draws both on these research findings and on interviews conducted by the author in twelve desegregated urban school districts in different parts of the country. Unfortunately, there is very little systematic research on a number of the issues discussed in this article; thus this analysis should be understood more as an effort to point out potentially significant relationships to those who must make decisions based on imperfect knowledge rather than as a presentation of well-established social science findings. At this time, social scientists can perhaps be most useful to litigators and courts by suggesting more accurate conceptualizations of desegregation as a complex long-term process of institutional change than by pretending to have firmly established optimal formulae for easy application.

11. See Orfield, School Integration and Its Academic Critics, 5 Civil Rights Digest 2 (Summer 1973); N. St. John, School Desegregation Outcomes for Children 16-43 (1975).

12. 1-2 National Opinion Research Center, Southern Schools: An Evaluation of the Effects of the Emergency School Assistance Program and of School Desegregation (1973) [hereinafter cited as SOUthern Schools].

13. See, e.g., studies referred to in notes $17,28,53,54 \mathrm{infra}$. 
On the basis of presently available evidence, the following general conclusions about the educational requirements for successful desegregation seem worthy of serious consideration in designing school desegregation plans:

(1) Successful desegregation requires basic adaptations in the teaching methods which prevail in most schools, but teachers find it very difficult to change well-established teaching approaches and expectations.

(2) Principals play a crucial role in the adjustment and adaptation of a school to its altered student body and community setting, both in providing educational leadership and in setting a social climate supporting desegregation.

(3) Desegregation often creates a readiness within schools to "integrate" the curriculum and these changes may well facilitate effective adaptation of the school. School systems, however, must provide for more than superficial training of staff in the development and use of new materials and teaching units. Furthermore, it is often incorrect to assume that minority teachers automatically are qualified to teach minority history or culture.

(4) Desegregation plans should be designed so that the educational programs needed by non-English speaking children are not disrupted; but there is no evidence at present to show that a bilingual program cannot be as effective or more effective in properly planned integrated bilingual schools.

(5) Successful desegregation is achieved most readily with children at the youngest age levels; children who begin their schooling in an integrated setting experience very few of the educational and social complications found among older children coming from previously segregated schools.

(6) The process of change and adaptation of the desegregated school usually takes place over several years; thus the typical approach-embodied in the federal desegregation assistance program ${ }^{14}$-of concentrating special resources in the period immediately before and after the desegregation process begins is probably far less helpful than continuing long-term support for a period of several years.

Desegregation as a Crisis for Teachers

Public attention in any school desegregation crisis tends to focus on angry citizens or on the children who are bused to a new school. The public hysteria soon recedes, however, and the students usually adapt fairly rapidly to a new status quo. But the teacher often faces a deeper and more persistent crisis-the

14. Emergency School Aid Act, 20 U.S.C.A. \$\$ 1601-19 (1974). 
professional crisis of realizing, consciously or subconsciously, that he or she doesn't know how to teach effectively children whose background is very different from that of the dominant group, or what had been the dominant group, in the school. Older teachers, who have long taught in middle class neighborhoods in schools which ignored the small numbers of children with serious learning problems, have a particularly traumatic adjustment.

Teachers in "good schools" with strongly motivated, high achieving, generally well-behaved, middle class children of ten have built their professional identity as good teachers around the successes of their students. In fact, these schools are often rigid, unimaginative institutions that do violence to students who cannot conform to school norms. The majority of these middle class students succeed because there is little the school could do to stop their success, given the enormous advantages they bring from their homes, reinforced through the interaction of the students among themselves. When these "good" teachers are confronted with large numbers of students who do not respond in the school's "typical" way, they must either blame the newcomers or recognize and acknowledge a very serious professional inadequacy. If they blame the students, the desegregation process is severely impaired. If they admit a need to modify their basic educational approach, then the desegregation crisis has presented a rare opportunity for institutional change. Desegregation plans should attempt to facilitate positive adaptations.

The desegregation transition is extremely difficult for such teachers. Although the problem is usually described as one of helping teachers come to terms with their personal prejudices, it often involves the more fundamental problem of helping experienced teachers learn a new way to teach. Many teachers feel severely inadequate. Principals report teachers crying in their offices during the first months, and school district curriculum consultants describe incessant appeals for advice about handling the new situation. The awareness that something is wrong is often widespread. In San Francisco, for example, a survey of teachers during the first year of desegregation found more than 60 per cent of the district's teachers agreeing that "our curriculum needs major revisions if it is to meet the needs of minority children in the integrated classroom." ${ }^{15}$ Of those favoring change the largest number mentioned development of techniques to respond to the range of individual needs in the classroom. ${ }^{16}$

An intensive year-long study of three desegregated schools in a California city school district during its fourth year of desegregation underlined some of the difficulties of the adjustment process. ${ }^{17}$ The change was particularly hard

15. San Francisco Unified School District, Evaluation of San Francisco Unified School District Desegregation/Integration, 1971-72, October 1972, at 164 (unpublished document available from school district offices).

16. Id.

17. M. Metz, Authority in the Junior High School: A Case Study, 1971 (unpublished doctoral dissertation, University of California at Berkeley). 
on the older teachers in a formerly high status school, called Hamilton in the study, which had served a solidly middle class neighborhood with an exceptionally high average educational level. Neither the teachers nor the principal had had experience with minority children. A number of teachers had been in the school for years: ${ }^{18}$

They stressed academic material above all else, and they expected punctuality, neatness, and deference to be displayed by the students as a matter of course. ... These teachers were for the most part used to dealing with middle class children only. Many resented the influx of lower class children with fewer academic skills, less orderly behavior, and less acceptance of adults. The teachers, some of whom had come to Hamilton to get away from such children, often had few methods for coping with this kind of child and low motivation to set about acquiring such methods.

Some of the older teachers were hostile, feeling their "comfortable school invaded by strange children with no respect for their ideas of what a classroom should be like."19 The major changes in this school came from a growing number of new faculty members who wished to teach in an integrated setting.

A survey of teachers conducted in two rural southern counties and one suburban county showed that the transition was particularly difficult for teachers who developed their teaching styles in white middle class schools. This is especially true of high school teachers, who were more likely to feel that their schools had not made a successful adaptation and that standards had been lowered. ${ }^{20}$ One white teacher in four reported that teaching had become less enjoyable. ${ }^{21}$ Teachers worried about cultural and communications differences, about how to deal with their own prejudices, and about finding ways to deal with diverse student needs. Forty per cent of the white high school teachers said they had lowered their standards, half of them saying they had modified grading practices to the point where they were "compromising their professional ethics." 22 Forty-four per cent of the white teachers said they would prefer teaching in a less-integrated school, and only about half the whites thought their schools had made adequate adjustments to the new situation. ${ }^{23}$

The black teachers in these three school districts responded very differently. A fifth of them said that they had raised their standards, 93 per cent said teaching was as enjoyable or more enjoyable than it had been before, and three-fourths preferred to continue teaching in integrated schools. ${ }^{24}$ These strong positive findings occurred even though the black faculty members were somewhat less optimistic about the success of their particular schools in adapting to the new situation.

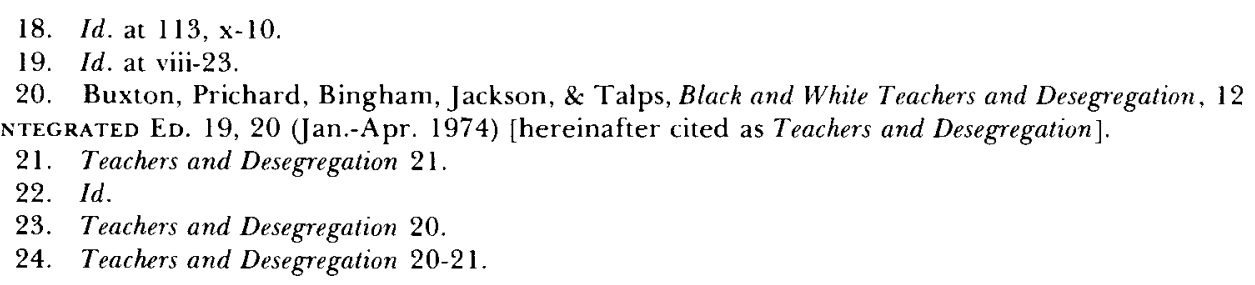




\section{The Central Role of the Principal}

Report after report on desegregated schools mentions the central role the principal plays in determining the school's response to the desegregation crisis. While in normal circumstances the principal's role may be ambiguous, his authority limited, and his job largely routine, when schools are suddenly reconstituted with substantial numbers of new students and faculty members from racial and ethnic groups not previously represented, the principal often becomes an extremely important figure. He must control and manage the early conflicts and tensions, build positive morale, strengthen school-community relationships, and help teachers work out better educational responses.

A 1972 study of principals in Virginia described the typical principal as "untrained for the almost overwhelming new task thrust upon him, lacking the power to do the job properly, seldom consulted by decision makers in the school district." 25 The desegregation process gave principals the role of "change agent." Eighty-six per cent of the Virginia principals included in the study recognized that they were "very important in setting the tone of acceptance of desegregation. ${ }^{26}$

Preliminary findings of research currently under way in New Haven and in the San Francisco Bay area highlight the importance of the principal's role. ${ }^{27}$ In both areas, principals have been central to the achievement of major educational adaptations in the schools.

The importance of the principal's role was underlined in a 1973 case study of the desegregation process in four schools in a middle-sized northern city ${ }^{28}$ with a population of approximately 250,000 . The study concludes: ${ }^{29}$

[I]t is clear that the most favorable school environment-that which contributed most to good education, racial integration, and pleasant working conditions for the teaching staff-was to be found at the Highland Elementary School. This environment was due ... [primarily] to the principal's attitude of acceptance and his leadership skill.

Other studies of integrated schools reach the same general conclusions. ${ }^{30}$

25. M. Turnage. The Principal: Change Agent in Desegregation i (1972).

26. M. Turnage, supra note 25 , at $3,5-6,19$.

27. Comments by James P. Comer on work underway at the Yale Child Study Center and Elizabeth G. Cohen on work in progress at Stanford University, at The Courts, Social Science, and School Desegregation Conference, Hilton Head Island, S.C., Aug. 20, 1974, on file at Law and Contemporary Problems office.

28. C. Willie, Race Mixing in the Public Schools $11-12$ (1973).

29. C. Willie, supra note 28 , at 70 .

30. See, e.g., Useem, White Students and Token Desegregation, 10 INTEgrated Ed. 48 (Sept.-Oct. 1972). Pettigrew, A Sociological View of the Post-Bradley Era, 21 Wayne L. Rev. 813, 823 (1975). F. Wirt, Contemporary School Turbulence and Administrative Authority 24, October 30November 1, 1974 (unpublished paper prepared for David W. Minar Memorial Conference on Problems in the Politics and Governance of the Learning Community, Northwestern University). 
Within the school organizational structure, there is probably no real substitute for leadership by the principal in adapting the school to its new educational responsibilites: ${ }^{31}$

Highly specialized supervisors may tend to drive curriculum areas farther apart, not bring them more closely together-unless an overview of the total supervisory service in a school is an operating part of the principal's job. This point cannot be overemphasized; it is the principal whose vantage point enables him to see all of the various aspects of the school program in its totality.

... The point we make is that if the elementary school principal does not assume the responsibility for developing and improving curriculum and instruction in his building, no one else will.

Principals may also hamper the desegregation process. A recent survey of the attitudes of principals in three major Texas cities suggests considerable hostility toward the desegregation process. ${ }^{32}$ While the low response rate to the survey (47 per cent) dictates that the results be read with a great degree of caution, principals reported considerable resistance to racial change. Twothirds of the white, all the Chicano, and nearly half the black principals opposed busing. ${ }^{33}$ Black principals, however, were two and one-half times more likely to approve of busing of their own children than principals in the other categories. ${ }^{34}$ Two-thirds of the black principals, but virtually none of the others believed that the federal government should take a more active role in desegregation. ${ }^{35}$ Two-thirds of the white and most Chicano principals were concerned about dating and inter-marriage, and a third of each non-black group thought that "stereotyping black children as lacking ambition causes no harm."36 A substantial minority of the white and Mexican-American administrators disputed the proposition that "most Negro families are stable and law abiding." ${ }^{37}$ About a fourth of the white principals thought that integration would diminish educational quality for white students. ${ }^{38}$ Solid majorities of each group agreed that administrators "have much effect on racial issues" and that they needed "more minority training." 39

The Southern Schools report shows that schools with black principals, or white principals who strongly support integration, fare far better in making the process work. ${ }^{40}$

31. Curtin \& Gilbertson, The Principal and the Instructional Program, in The Elementary SCHool Principal in Action 124-25 (L. Bradfield \& L. Draft eds. 1970).

32. The three cities are Dallas, Houston, and San Antonio. See Stones, School Administrator Attitudes and Racism, 11 INTEGRATED Ed. 54 (Mar.-Apr. 1973).

33. Id. at 57 .

34. Id.

35. Stones, supra note 32 , at 58.

36. Stones, supra note 32 , at 54,56 .

37. Stones, supra note 32 , at 56 .

38. Stones, supra note 32 , at 57.

39. Stones, supra note 32 , at 58 .

40. Narot, Teacher Prejudice and Teacher Behavior in Desegregated Schools, in 2 SOUTHERN SCHOOLS 17,31 . 
If the principal is black, teachers are less prejudiced. (Since, in at least some cases, the principal is free to choose his staff, this may reflect recruitment strategy rather than influence.) Teachers are also perceived as less prejudiced both by other teachers and by students. In addition, when the principal is black, teachers are more positive in their evaluation of desegregation. . . In general, the more racially liberal the principal, the more liberal are the teachers, and the more favorable the [white] student's perception of them.

.. [An indication that the principal] has spoken to the faculty about racial issues ... is an important predictor of black student perceptions of the staff. Principal's race, racial liberalism, and willingness to talk with the teachers in the school are the three largest predictors of black student perceptions of staff attitudes.

As the school's crisis manager, faculty leader, and chief disciplinarian, as well as the school's "contact point" with parents and community, the principal has many ways to express his attitudes and make his views felt. It is hard to conceive how a school could successfully undergo basic and difficult change without at least tacit support from the principal.

If further, more systematic, research sustains the early findings on the importance of the principal in the desegregation process, it will have some obvious implications for desegregation planning. The fact that desegregation in the South has usually been accompanied by decisions shunting black principals aside to other jobs may well mean that southern districts have sacrificed one of their most valuable resources for making desegregation work. ${ }^{41}$ The significant growth in the number of minority principals in the border and northern states, on the other hand, should provide real assistance in the desegregation process.

While it is obvious that principals with extraordinary talent and dedication are a great asset to any school system, it is hardly in the power of the courts to expand the supply. What is important, from the standpoint of desegregation planning, is that principals with certain attributes seem to handle the process of transition more effectively. Desegregation plans might include efforts to provide extensive in-service training for principals, and require affirmative recruitment and upward mobility programs. Searching scrutiny of the jobrelatedness of certain certification requirements that have tended to screen out otherwise qualified minority administrators should also be undertaken. Understanding and support for the process of bi-racial or multi-ethnic integration should itself become a major job qualification, one that could perhaps be institutionalized through a screening process representing the various affected community groups.

41. The dramatic decline in the number of black principals in southern schools after desegregation has been repeatedly documented. See Hearings on Displacement and Present Status of Black School Prinicpals in Desegregated School Districts Before Senate Select Comm. on Equal Educ. Oppontunity, 92d Cong., 1st Sess. (1971); Freeman, Desegregation. Political Power, and the Employment of Black School Teachers 5. September 1974 (unpublished paper, Harvard Institute of Economic Research); Butler, Black Educators in Lonisiana-A Question of Survival, 43 J. Negro ED. 9, 22-24 (1974); Egerton, When Desegregation Comes, the Negro Principals Go, 3 Southers Ed. ReP. 8 (Dec. 1967). 


\section{IN-SERVICE Training}

One of the activities school administrators almost universally support and almost never evaluate adequately is in-service training for teachers and staff facing desegregation. Many school districts attempt rapidly to sensitize their staffs to the viewpoints of other groups through human relations training shortly before or after the desegregation process begins. This training is directed primarily to uprooting prejudices. Only after a long period, if ever, does the emphasis shift to curriculum changes. ${ }^{42}$

An evaluation of the impact of a human relations training program in Riverside, California provides some interesting results. ${ }^{43}$ The researchers found that the most effective efforts caused attitude changes "in both directions." 44 According to the evaluation: ${ }^{45}$

The graph reveals that the leader who created the most change in a positive direction also created the most change in a negative direction. In other words, within the group that had the greatest number of "gainers" there was also the greatest number of "losers." Conversely, in the one group that had the least number of "gainers," there were also the least number of "losers." As has been expressed elsewhere, this is interpreted to mean that a vigorous and open exchange of feelings and emotions may indeed bare the individual's feelings, but that this causes the individual to more strongly adhere to whatever vieupoint he previously held. If he happens to be. for example, in favor of a greater amount of racial integration and a greater understanding and acceptance of cultural variation, etc., then the individual will travel in that direction. Conversely, if an individual seems to be of a mind not to change toward that direction, he will, after having expressed his riews, form even more rigid opinions or be less willing to adopt the feelings which are contrary to his own way of thinking.

While this evaluation in itself is a wholly inadequate base upon which to pass judgment on a great variety of programs in very different circumstances, it at least raises some questions about possible alternative approaches to inservice training. If one concedes that short-term emotional sessions are unlikely to restructure deeply rooted prejudices, the question arises about whether inservice training resources might not be more appropriately applied to conveying needed factual information (about teaching minority history, for example) or to assist in the development of new teaching styles. Such approaches would probably encounter far less resistance, since they fit teachers' notions of "professional" activities and they meet immediate day-to-day classroom needs, particularly if carried out after the desegregation process is under way.

42. Interview with Richard Foster, Superintendent of Schools, in Berkeley, Calif., Oct. 27, 1972.

43. T. Carter, E. Casavantes, \& C. Fowler, Final Report and Evaluation of the Riverside In Service Institute, Dec. 1, 1967 (unpublished document available from authors).

44. Id. at 9 .

45. Id. 
Another approach might be to concentrate, at least initially, on training of principals. Since the principal's racial attitudes and ability to support curricular experiments appear to play such an important role in the successful adaptation of a desegregated school, this might be a logical focus for intensive use of scarce resources.

Social science research cannot determine what is the most appropriate inservice training for varying circumstances. What social scientists can do is to raise some questions about overly simplistic and possibly counter-productive approaches. If the desegregation process is understood to be one requiring a long-term educational adaptation of schools, then it may well be appropriate to divert some funds from short-term human relations sessions to long-range curriculum development and training in new methods of instruction.

\section{IV}

\section{Tracking and Ability Grouping}

A. The Difficulties Inherent in Simultaneously Desegregating and Eliminating Tracking

The need for institutional change becomes evident when one considers the educational implications of a movement away from a tracking system at the secondary school level. While it is easy to say that inter-classroom (and sometimes even intra-classroom) segregation can be eliminated by prohibiting the track system, it is important to consider the implications of taking this step without the necessary supporting educational changes. For example, what would be the consequences of suddenly placing newly desegregated Chicano high school seniors in the traditional college-oriented English literature class a teacher has taught in the same way for the past fifteen years? If the teacher offered a full year of Chaucer, Shakespeare, and Milton to a class where there was now a ten-grade range of reading and composition achievement scores, with some children lacking English fluency, some students would be targeted for failure and humiliation. In this situation, many students would probably prefer tracking, and, indeed, tracking might well do less damage to them.

If the teacher is to come to terms with the increased diversity of the student body without resorting to ability grouping, watering down the existing curriculum to the least common denominator, or blaming the children, he or she often must develop a new teaching style employing some form of individualized instruction, helping each student to build on his strengths and overcome his weaknesses. Experience shows that individualized instruction is a feasible alternative for many elementary school teachers and probably for certain secondary level courses. Until we are confident that it will work in high schools generally, I believe we should avoid taking a rigid position in opposition to high school tracking, particularly if there is significant integration within each 
track. The Department of Health, Education, and Welfare, which has been actively following a policy of ending in-classroom segregation by ability grouping at the elementary level, has not at this time put strong pressure on the high schools to do the same. ${ }^{46}$

The extremely difficult problem of teaching students with a wide range of achievement levels is apparent in responses to a survey of seventh grade teachers in the Presidio Junior High School in San Francisco. One wrote: ${ }^{47}$

A teacher in Jr. High School faced with a range of reading ability from 2 nd grade to $9 \mathrm{th}$ or $10 \mathrm{th}$ grade-all within one 45 minute period-finds herself frustrated to the utmost. How can she save the below-grade student from suffering more pain-how can she keep him from feeling failure-how can she keep the above average student from boredom?

Another teacher wrote that "ability in class is too widespread," 48 while a third said that "it takes about three times as much time to cover materials." 49 Teachers in that school responded to the challenge in very different ways. One said that he had to "water down the course to what they can do in class or else they get left behind and then become behavior problems." 50 Another wanted restoration of the track system. Some faculty members, however, sensed the need to respond to changing attitudes and ability spectrums with "a new approach to teaching." $\overline{1}$ One teacher commented that while the furor over busing would die down, "our lack of adequate positive learning programs will cause trouble year after year until we improve considerably." 52

When the Berkeley school system decided to end tracking in 1968, its leadership recognized the simultaneous need to adopt a new teaching style. "Groupings will be flexible," said Superintendent Neil Sullivan, "and individualized instruction in small groups will be emphasized." ${ }^{, 3}$

In a detailed case study of an integrated school in White Plains, New York, a teacher and parent-volunteer are reported to have come to similar conclusions: ${ }^{54}$

How can we teach children of widely varying abilities and skills in one classroom without discouraging the less able and holding back the fast learners? This is a problem that arises in any classroom.... In an integrated classroom, however, it is underlined by the racial issue. . . Children who are

46. Interview with Lloyd Henderson, Director, Education Division, HEW Office for Civil Rights, Washington, D.C., Sept. 30, 1974.

47. San Francisco Unified School District, Zone I, Evaluation Report \#5, July 1972, at 35 (unpublished document available from school district offices) [hereinafter cited as Evaluation Report \#5].

48. Evaluation Report \#5, at 37.

49. Id.

50. Evaluation Report \#5, at 41.

51. Evaluation Report \#5, at 42.

52. Evaluation Report \#5, at 43 .

53. N. Sullivan, Now is the Time: INtegration in the Berkeley Schools 159 (1969).

54. I. Schlesinger \& M. D'Amore, Children in the Balance 99-100 (1971). 
made to feel frustration and failure at the academic level and who are forced to attend a class in which they cannot meaningfully participate become bored and begin to look upon themselves as worthless. They will then try to draw attention to themselves by any means they can devise. . .

The only approach to teaching that makes any sense in human terms, it seems to me, is individualized instruction. This means that we must recognize the fact that every child learns at his own pace and in his own way. In a classroom full of children of the same age group, every student will have mastered different skills to a different degree.

They favor a system diagnosing the particular skills of each student and prescribing carefully defined sequential materials to meet each student's particular needs. The system, when properly implemented, shows the tremendous variation among both minority and majority children and gives each child specific, highly structured tools which can help him meet his needs. This is a drastic departure from the normal system where the rule is: "All should know this, and those who don't are behind." 55

There is some confirmation for the importance of a change in teaching methods, and the impact of tracking, in very fragmentary data in the Southern Schools report. The study included only two schools which relied on individualized approaches, in an effort to minimize the pressures students were feeling from direct competition. In both of these schools the investigator reported "extremely positive racial tension scores," scores "on the far end of the distribution of scores." ${ }_{56}$ The authors offered a hypothesis: ${ }^{57}$

Teaching machines and other individualized forms of instruction allow students to move at their own pace without tracking. There is a definite stigma attached to being in a class for slow readers. Working with an individualized programmed teaching machine lets every student move at his or her own pace with no stigma attached to it.

Tracking, on the other hand, had a "consistently strong negative effect" on the students' attitudes toward integration at the elementary school level. ${ }^{58}$ The study also has some evidence that pro-integration attitudes are better developed in non-tracked elementary schools in rural areas than elsewhere. ${ }^{5 y}$

The study shows a very different picture, however, at the high school level. At this level, where white students possessed extreme stereotypes of black inferiority and had opposed integration, tracking-which lessens racial contact in integrated high schools-seems to have some positive impact in fostering more favorable racial attitudes. ${ }^{60}$ While this finding on tracking is only an isolated finding, it does suggest that in certain situations abolition of tracks at the high school level may not be helpful. The practical problems of managing a high

\footnotetext{
55. Id. at 101 .

56. 1 Southern Schools 124.

57. Id.

58. 1 SOUTHERN SCHOOLS 74.

59. I SOUTHERN SCHOOLS 81 .

60. I SOUthern Schools 83, 87
} 
school class in certain courses where there is no ability grouping can be very formidable. In cases where the students are entering high school classes from segregated schools which have built up both racial stereotypes and achievement gaps, the problems can be even more severe. While I observed substantial efforts to transform elementary schools and some intermediate schools in desegregated districts across the country, most school administrators expressed very little optimism about the possibility of basic change at the high school level.

\section{B. Research on the Effects of Ability Grouping}

A recent review of the results of some fifty years of educational research on the effect of ability grouping on children concluded that the research was contradictory, often of low quality, and limited largely to simplistic studies which attempted to measure the impact of ability grouping on test scores without adequate statistical controls on other factors influencing the learning process. ${ }^{61}$ The research on achievement levels has been said to be "at best, mixed, inconclusive and indefinite."62 To the extent that one could say anything, the data suggest some possible gains from ability grouping for the most able students, but "almost uniformly unfavorable evidence" for average and below-average students. ${ }^{63}$

On the more complex issue of the impact of ability grouping on the selfesteem of children, the research was even less adequate and had produced "at least some data to support almost any stand one might take on this issue." The evidence was certainly insufficient to document the widespread belief among educators that low ability children developed more desirable attitudes and self-esteem in classes with narrow ability ranges. ${ }^{65}$ Some recent studies suggest that tracking may act to "inflate the self-esteem of children assigned to relatively high ability groups, and to reduce the self-esteem of children assigned to average and low ability groups," but this finding is not firmly established. ${ }^{66}$

The defects of the existing research literature are greatly magnified when one attempts to adapt curriculum and tracking programs designed for a stable, non-integrated school in a typical white, middle class neighborhood structure to accommodate minority students who often come to the new school years behind in achievement levels and find they must confront older faculty members who find it difficult to change the way they teach. This situation presents

61. Eposito, Homogeneous and Heterngeneous Ability Grouping: Principal Findings and Implications for Evaluating and Designing More Effective Educational Environments, 43 REv. ED. RESEARCH 163, 167 (1973).

62. Id.

63. Id.

64. Eposito, supra note 61, at 168.

65. Id.

66. Id. 
very special educational challenges and suggests the need to avoid overly simplistic legal principles which might possibly damage minority children.

The complexity of the tracking issue is further heightened, as Edgar Epps points out, ${ }^{67}$ if one conceives of the high school not as an institution primarily for cognitive learning, social adaptation, and personal fulfillment, but as an institution for filtering and channeling students to higher education and other career opportunities. Some existing data suggest better college placement for black students who are enrolled in integrated schools. ${ }^{68}$ By the same token, it seems extremely likely that enrollment in a college preparatory track is strongly associated with eventual college enrollment, everything else being equal. Lawyers and others involved in the negotiations on remedies should keep in mind the very difficult challenge the process poses, particularly to teachers from middle class white schools. Perhaps a strategy for litigating the tracking issue at the high school level might be built around a requirement of open enrollment for the upper tracks. To the extent possible, school desegregation plans should include in-service training of teachers and provision of teacher aides or trained volunteers to handle the additional burdens of individualized instruction, and retraining of the counseling staff to avoid racial channeling. At the same time, tracking and ability grouping in the elementary grades should be ended. Finally, recruitment and retention of minority teachers should be urged as they seem to be able to adapt to integrated situations more easily.

\section{V}

\section{INTEGRATing The Curriculum}

In striking contrast to the situation a few years ago, educators now have available a broad array of integrated and black-oriented teaching materials. A major study of American history texts, undertaken in 1972 by a leading critic of the neglect of minority contributions in such texts, concluded: ${ }^{69}$

The time has come ... to praise what the American-history textbooks have at this point of time achieved in their treatment of black Americans. . . . Whatever weaknesses and gaps still linger among a very few of the texts of the $1970 \mathrm{~s}$, the attention given to the black American experience is many times greater than that given to any other minority group....

... Indeed, many of the texts are sold and promoted as texts which tell the story of America in terms of the peoples of the nation. . . Beyond that, however, there are some texts which have achieved to near perfection a fully integrated American-history textbook.

67. Statement made at The Courts, Social Science, and School Desegregation Conference, Hilton Head Island, S.C., Aug. 20, 1974, on file at Law and Contemporary Problems office.

68. See, e.g., Armor, The Evidence on Busing, 28 Pub. Interest 90, 114 (Summer 1972). Armor's critics claim that he actually understated this positive finding in his analysis of Boston area deseg. regation. A major retrospective study of blacks educated in integrated schools found a positive relationship for college attendance, particularly for those with elementary school integration. Crain, School Integration and the Academic Achievement of Negroes, 44 Sociology of ED. 1, 5-7 (1971).

69. I. Sloan, The Negro in Modern American History Textbooks 4 (4th ed. 1972). 
The new texts can be found in urban and integrated school systems across the country-even in conservative areas of the South.

More interesting, perhaps, is the extensive revision of curricular materials now under way in desegregated areas and districts. In 1972, for example, the South Carolina State Department of Education released a guide on Ethnic Contributions to U.S. History. The guide, developed by a statewide committee, is based on the premise that all children in the state need a better understanding of black contributions, a need particularly clear now that the schools are desegregated. The committee concluded: ${ }^{70}$

No history course should leave an individual with a sense of inferiority.... Every community and school district must rise above the conditions of mistrust which divide and destroy the fabric of any society. If one group insists on espousing superiority over another, we all lose.

The guide departs dramatically from the orthodox southern treatment of the Reconstruction period, reflecting the perspective of recent revisionist works by black and white scholars. "Negroes led the way," the guide says, "in democratizing state constitutions, guaranteeing equal rights, and developing programs of state-financed education, agricultural experimentation, et cetera." $\tau 1$

A program in Jacksonville, Florida reflects another approach. Working with local black college students, the project helped reconstruct the unrecorded history of the community through old scrapbooks, diaries, and oral history to describe the local roots of blacks who later played a national role. Thus to facilitate desegregation, the schools helped to create a black history of the community.

Recognizing that the curriculum materials built around the experiences of blacks in Harlem or Watts might have very little relevance to that of children growing up in an urban southern community with a different cultural tradition, the Duval County school system in Jacksonville, Florida initiated a project of preparing "learning activity packages" based on the history of the local black community. ${ }^{72}$

One of the serious problems for curriculum planners has been the continued lack of good materials for non-black minorities. While publishers have responded to the demands for a more accurate portrayal of the nation's largest minority, they have been much slower to develop materials on Chicano, Puerto Rican, Indian, and other minorities which have contributed to American society. School systems have been forced to improvise. The Minneapolis school system developed materials dealing with Indian tribes which account for a

70. South Carolina State Department of Education, Ethnic Contributions to U.S. History, 1972 (mimeograph curriculum guide prepared by statewide committee in cooperation with the Charleston, S.C. School District).

71. Id. at 22 .

72. Interview with Delphenia Carter and Benetta Sherard, Duval County Schools Multi-Ethnic Program, Jacksonville, Fla., Dec. 8, 1972. 
substantial fraction of the district's minority enrollment. ${ }^{73}$ When fifth graders study the westward movement of settlers, for example, they devote considerable attention to the problem of Indian land rights and the ways in which the whites' takeover of the land and establishment of the reservation system destroyed tribal ways of life. In the sixth grade, the history curriculum portrays the historic role of the Chippewa and Sioux peoples. Because of the paucity of good materials on Minnesota Indians, the district commissioned an Indian educator to develop a series of filmstrips and tape cassettes dealing with tribal economies, commonly portrayed stereotypes held by whites, reservation life and schooling, tribal history, and the changes that Indian children face moving from the reservation to the city.

A basic purpose of American public education has been to convey to students a common understanding of our history, our political institutions, and our national purpose. The image conveyed, however, has usually been one of white Americans devising and operating extraordinarily successful political institutions in a society that had solved most of its problems. The rapid change to materials that emphasize diverse contributions to American society, that deal much more openly with the nation's historic failings, and that present a range of views about contemporary controversies represents a very important curricular shift. Unfortunately, there is extremely little research so far that evaluates its impact.

A recent study of 104 third grade students discloses an impact on racial attitudes of the students attributable to the discussion of books which deal with "black feelings, situations, ideas, and the contributions that black Americans have made to cultural, political, and scientific developments in the United States." ${ }^{4}$ By testing the seven-year-old children before and after classroom use of six books on the black experience, the research concludes that "reading and discussion of multiethnic social studies materials can influence attitudes toward black Americans in white urban and rural children of early childhood age." Such early exposure, the author suggests, influences the basic "response sets" of the children. ${ }^{76}$

One basic weakness in adopting a multiethnic curriculum is the fact that few teachers, including minority teachers, have any training in these areas. Far too frequently, the task of preparing new teaching units is assigned to teachers lacking adequate academic preparation in the fields. ${ }^{i 7}$ The result is often trivial or misleading material which does not become an integral part of the general

73. Interview with Christian Skjervold. II. Project Administrator, Task Force on Ethnic Studies, Minneapolis Public Schools, Minneapolis, Minn., Oct. 19, 1972.

74. Yawkey, Attitudes Toward Black Americans Held by Rural and Urban White Early Childhood Subjects Based Upon Multi-Ethnic Social Studies Materials, 42 J. Negro Eo. 164, 166 (1973).

75. Yawkey, supra note 74 , at 167 .

76. Yawkey, supra note 74, at 167-68.

77. The pattern in many school districts receiving federal aid funds has been to assemble a small team of teachers, without special training, who then spend a summer preparing teaching 
curriculum. Even when good materials are obtained or developed, faculty members usually are not provided with the professional training they need to use these resources.

In many districts "black studies" or other minority group courses have been a central point of tension and conflict, particularly within high schools during the early part of the desegregation process. This often results from the failure of the formerly white schools to make any move toward curriculum change or even to recognize Black History Week or major ethnic holidays.

The initial stopgap response of many school districts is to set up special elective high school courses for interested minority students while leaving the basic, required courses largely untouched. For the 1970-71 school year, for example, 937 American high schools reported offering such courses, but they enrolled only seven-tenths of one per cent of the national enrollment. ${ }^{78}$ The U.S. Civil Rights Commission reported that less than 2.5 per cent of Chicano elementary students and less than one per cent of secondary students in schools of the Southwest were enrolled in special courses in Mexican or MexicanAmerican history. ${ }^{79}$ The courses enrolled few Anglo students, and some administrators reported that these courses are completely segregated. ${ }^{80}$

These separate courses have been widely criticized, and many curriculum planners believe they will eventually be displaced by integrated basic courses. In Miami, for example, Richard White, head of the program development office, recalls how the huge Dade County system "went through the whole sequence." ${ }^{81}$ In the beginning, separate black history and literature courses were developed and installed at all high schools and there was strong initial student response. Three or four years later, however, the courses were rapidly being eliminated because not enough students were enrolling to justify the cost of an additional teacher. As a result, the system is now working on building new materials into the general curriculum.

Although there is little social science evidence on the merits of the alternative approaches, enrollment statistics strongly suggest that if the new perspectives are to reach most minority children and more than an insignificant fraction of Anglo children, they must be incorporated into the standard course curricula. Desegregation plans should require a review of the district's curriculum, and opportunities for substantial retraining of teachers in the fields most affected. From the perspective of managing the desegregation crisis, such an enterprise would have the additional advantage of alerting principals to

units. The quality varies enormously. Sometimes the units present outdated research findings or speculative judgments as facts.

78. D. Gertler \& L. Barker, Patterns of Course Offerings and Enrollments in Public SeCONDARY SCHOOLS 1970-71, at 12 (1972).

79. U.S. Commission on Civil Rights, Mexican american Education Study, Report Vi:

Toward Quality Education for Mexican Americans 9 (1974).

80. Id.

81. Interview with Richard White in Miami, Fla., Dec. 6, 1972. 
some minimum gestures of recognition of the new groups of students in their schools, a problem that has created considerable tension during the first year of desegregation in many high schools. ${ }^{82}$

Properly managed, then, desegregation offers an opportunity not only to revise teaching styles but also to unearth unconscious cultural biases in the curriculum. Desegregation makes an invisible problem suddenly very visible and creates both interest among teachers and a constituency within the student body for change. While courts should not dictate curriculum, a requirement that the district itself set up a fully representative review process and set aside resources for staff development would aid successful desegregation.

\section{VI}

\section{Desegregation and Bilingualism}

As the school desegregation drive moves from the South into northern and western cities, desegregation plans are being drawn in school districts which have considerably more complex social groupings than are found in the South. A body of law practice, devised to deal with desegregation of English-speaking blacks who share large elements of a common culture, cannot be transported without adaptation into systems where there are a variety of racial and ethnic groups, widely diverse cultures, and large numbers of students whose basic language is not English. When the Supreme Court declared, in the Keyes (Denver) case ${ }^{83}$ that "Southwest Hispanos and Negroes have a great many things in common" and that in Denver they "suffer identical discrimination in treatment when compared with the treatment afforded Anglo students," it was surely over-simplifying a complex issue. The resulting district court decision, however, permitted the retention of some segregated bilingual programs for children requiring language training assistance. ${ }^{\mathbf{8 4}}$

The San Francisco school board has recently ordered revision of the city's desegregation plan to prevent the transfer of Chicano students who are now in schools providing bilingual education. ${ }^{85}$ The Supreme Court's decision in Lau $v$. Nichols ${ }^{86}$ has sustained HEW's power to require school districts to provide special programs for children without a working knowledge of English. But if programs for Spanish-speaking children and other linguistic minorities continue to be operated on a segregated basis, these programs will conflict with the goals of a desegregation plan.

No significant research has yet been undertaken on bilingual-bicultural

82. See, e.g., Melton v. Young, 465 F.2d 1332 (6th Cir. 1972); Smith v. St. Tammany Parish School Bd., 448 F.2d 414 (5th Cir. 1971), aff'g 316 F. Supp. 1174 (E.D. La. 1970). See also Caldwell v. Craighead, 432 F.2d 213 (6th Cir. 1970), cert. denied, 402 U.S. 953 (197I).

83. Keyes v. School Dist. No. 1, 413 Li.S. 189, 197-98 (1973).

84. Keyes v. School Dist. No. 1, 380 F. Supp. 673, 692 (D. Colo. 1974).

85. San Francisco Chronicle, June 12, 1974, at 6 , col. 1 .

86. 414 U.S. 563 (1974). 
programs or even on the question of whether such programs are the best remedy for children with English language problems. A recent review of the research reports that there are only four studies which were carefully controlled and truly experimental; only one of these was undertaken in the United States. ${ }^{87}$ At present, substantial numbers of Spanish-speaking children are achieving at well below grade level. Most of the argument for bilingual and bicultural programs is based on the assumption that education in the child's own language would be more effective than education in English. However, it has been urged that other approaches should be examined: ${ }^{88}$

\begin{abstract}
Alternative hypotheses as to the failure of the educational process for Spanishcultured children should also be considered. It may be that better prepared and more sensitive teachers who do not have low expectations and negative stereotyped views of the children they serve may produce results better than or equal to those produced by bilingual/bicultural education progams.
\end{abstract}

Many of the federally funded bilingual programs operate in segregated schools. If, however, the Coleman Report's general finding - that the background of the other children in the classroom affects learning far more than does the quality of the teaching staff ${ }^{89}$-applies to Spanish-speaking children learning English, one would expect more reinforcement for mastery of the new language in a classroom and school with many English-speaking children. The rapid loss of foreign language mastery for English-speaking children who have no regular opportunity to use the new language, except with their teacher, might be replicated for children learning English in a context where all the informal conversation is Spanish. These are questions in urgent need of research. As the federal government channels growing sums into bilingual education, ${ }^{90}$ state legislatures enact legislation requiring bilingual education, ${ }^{91}$ and the courts begin to be confronted with these questions, ${ }^{42}$ the need for reasonably clear information on what works best grows increasingly serious.

Social science findings about the desegregation process can lend support to some common sense principles in dealing with the large numbers of non-black minority students affected when a school system is forced to devise a desegregation plan. It is only rational, for example, not to distribute children needing intensive language training so thinly across a school system that it becomes administratively impossible to offer them the help they need. While distributing minority children on a fixed ratio across a school system may be a sound

87. See 1 R. Crain, Design for a National Longitudinal Study of School Desegregation $71(1974)$.

88. Id. at 74

89. J. Colmman, Equality of Educational Opportunity 302 (1966)

90. See Bilingual Education Act, 20 U.S.C. $\$ 880$ b (1970).

91. See, e.g., Mass. AnN. Laws ch. $71 \mathrm{~A}, \S 2$ (Supp. 1974). Many other states have recently enacted statutes authorizing-rather than requiring-bilingual education programs. See, e.g., Tex. Educ. Code $\$ 21.109$ (Supp. 1974); Cal. Educ. Code $\$ 5761.4$ (1975)

92. Se', e.g., United States v. Texas Educ. Agency, 467 F.2d 848 (5th Cir. 1972). 
"starting point" to remedy segregation of blacks, as the Supreme Court held in Swann, ${ }^{93}$ it is probably a poor remedy for linguistic minorities present in relatively small numbers in the school system and needing special programs which cannot feasibly be offered in all schools because of the cost and the shortage of qualified staff. Secondly, it is a serious mistake to develop desegregation plans which consider Chicano students as "Anglos" and use them to desegregate black schools. ${ }^{94}$ One of the few consistent findings in desegregation research is that the educational value of desegregation comes basically from the placement of lower income children in educational settings with more "advantaged" students. ${ }^{45}$ The Houston ${ }^{96}$ and Miami" plans for desegregating black schools by mixing Spanish-speaking children with black children-thus dealing with the issue of the racial identifiability of a school by adding another victimized minority-make no sense educationally.

Desegregation litigation in devising workable remedies (as the Supreme Court recognized in the Keyes case), should consider large distinctive ethnic minority groups as separate categories. The major ethnic minorities are distinctive in history, culture, educational background, and aspirations, as well as language. Thus conscious planning built around the special situation of each major group victimized by past segregation is essential. The problem is exacerbated by the continuing shortage of adequate texts for non-black minorities. ${ }^{98}$

\section{VII}

\section{Priority for Desegregation at the Earlest Grade Levels}

One of the few points of consensus in desegregation studies and in interviews of school officials is that young children experience the least difficulty in adapting to desegregation. This fact is probably because elementary school children have fewer stereotypes, even in the Deep South. ${ }^{99}$ In addition, the achievement gap between white and minority students at the elementary school level is much smaller than at the upper grade levels, ${ }^{100}$ and some research has suggested that integration at the earliest level can substantially diminish the characteristic year-by-year widening of the achievement gap between white and black children. ${ }^{101}$

93. Swann v. Charlotte-Mecklenburg Bd. of Educ., 402 C.S. 1 (1971).

94. See. e.g., Ross v. Eckels, 434 F.2d 1140 (1970).

95. This proposition is supported by the Coleman Report (see J. Colemas, supra note 89, at 320-25), by the extensive reanalysis of the Coleman data contained in ON Equality of EnvCaTIONal Opportunity (F. Mosteller \& D. Moynihan eds. 1972), and by the analysis of the Southern Schools studies, Narot, The Effects of Integration on Achievement, in 2 Southern Schools $61,68$.

96. Se Ross v. Kckels, 434 F.2d 1140 (1970).

97. See Pate v. Dade County School Bd., 434 F.2d 1151 (1970).

98. Sep L.S. Commission ox Civil. Rights, supra note 79 at $7-8$.

99. Se' I SOLTHERN SChOOLS 45-47,79.

100. See J. Colfman, supra note 89, at 274-75.

101. S'e, e.g., M. Purl, The Achievement of Pupils in Desegregated Schools, March 1971, at 4 (unpublished document on file with the Riverside Unified School Distric1, Riverside, Calif.). 
Pettigrew summarizes the sociological argument for early integration: ${ }^{102}$

\begin{abstract}
Racial isolation is a cumulative process. Its effects over time on children of both races make subsequent integration increasingly more difficult. Separation leads them to grow apart in interests and values. [The] Coleman [Report] showed that black children who had begun their interracial schooling in the first five grades evinced higher achievement test scores ... . And specific studies in Hartford, Connecticut, Ann Arbor, Michigan, Newark-Verona, New Jersey, Bridgeport-Westport, Connecticut, and Riverside all show the best achievement gains for those who begin desegregation in kindergarten and the first grade .... The Coleman data also indicate that the most positive attitudes toward having interracial classes and blacks as close friends are found among white children who begin their interracial education in the earliest grades...
\end{abstract}

From the school's perspective, the nature of the subject matter at the elementary level may make elementary school curricula more adaptable to individualized procedures than curricula for upper levels. Primarily concerned with developing student mastery of certain basic skills, the elementary schools deal largely with cumulative bodies of knowledge graded by levels of difficulty. Subjects such as reading, arithmetic, spelling, punctuation, and writing, can be broken down into small segments, often logically related. With properly designed materials and procedures, teachers can handle students operating at very different levels within the same classroom without inordinate difficulty. Primary school teachers tend to be more flexible and less wedded to traditional ways of teaching traditional bodies of knowledge than the subject-matteroriented teachers in the higher grades.

Desegregation plans that operate on the assumption that children should remain in their neighborhoods for the first grades and then transfer to desegregated schools can find no support in social science research. The information we do possess about the operation of the process strongly argues for making early desegregation a top priority in litigation and planning. This is one of the few clear and unambiguous recommendations that can be made on the basis of the existing research.

\title{
VIII
}

\section{Integration as a Long-Term Process}

The usual focus of attention is on the desegregation "crisis"-the period just prior to desegregation, when plans are being developed, through the actual accomplishment of those plans and after the conflicts within the community or within the student body largely have ended. This is the period when community leaders actively discuss desegregation, when the press covers the process, and when school authorities often receive some special federal ${ }^{103}$ and/or local funds to ease the transition. This is also the period when the desegregation process is evaluated by researchers.

102. Penigrew, supra note 30, al 822. See also I Southers SCHOOLS 53.

103. See, l'g. Fmergency School Aid Act. 20 U.S.C.A. $\$ \$ 1601-19$ (1974). 
This "transitional" period is very important. Administrators must deal with frictions and tensions and confusion both within the schools and within the community. During this period, school officials primarily are concerned with the restoration of some semblance of normality. They must deal in an atmosphere where minor fights are seen as serious racial incidents. School officials, in an effort to reduce tensions, provide human relations training for staff members, and try to reassure worried parents. It is a vitally important job to diminish community hostility and maintain morale within the schools. In educational terms, however, this is usually a period of defense of the status quo.

Since the assumption is that when calm has been restored, integration has been accomplished, the attention of the public recedes, and resources provided to assist in the desegregation process are withdrawn. However, the really significant changes may be just beginning. In the schools that I have visited, adaptation to desegregation is almost invariably seen as a process requiring several years, including replacement of some of the personnel. Published case studies often reflect the same conclusion. ${ }^{104}$ This suggests the importance of incorporating into desegregation plans a program of several years' duration, designed to help principals and teachers develop educational processes responsive to their new student bodies.

There is virtually no large scale research on this particular issue, so that this section of the article will examine changes in individual schools and present what some involved officials and academic observers think happens as desegregated schools try to move toward successful integration.

Thomas Phillian, a principal in Riverside, California, has been through the process of educational change following the desegregation of two schools. ${ }^{105}$ Palm School, a white middle class school, had an older, closely-knit faculty, most of whom were unprepared for desegregation and who worried about a decline in the school's high test scores. Teachers had tended to ignore the small number of white children with serious learning problems. Although the Riverside administrators strongly supported desegregation, the transition at Palm School was difficult and traumatic. Teachers who had been doing the same thing for fifteen or twenty-five years suddenly found they really didn't know what to do. At first, he says, "They just cried a lot."

Phillian began to work for change by scheduling two meetings a week to talk over articles and see films on new educational approaches. Teachers began to visit other schools which were trying new procedures. Even with this intense effort, it took almost a year and a half before the faculty calmed down and the first changes were made. A much longer time was required to change the basic teaching style of the school.

104. See M. Metz, supra note 17

105. Interview with Thomas Phillian, Principal, Adams Elementary School in Riverside, Calif., Oct. 27, 1972 
After achieving some success at Palm School, Phillian took over the troubled Adams School in the middle of the 1970-71 school year. The student body there included two hostile groups of Chicano students from different parts of town. Guns, knives, and chains were found in the school, and children called it "the prison." At Adams teachers had retained traditional tracks and had segregated classrooms. Phillian told the teachers that they would have to change or quit and closely monitored those he judged inadequate until some left. Openings were filled by enthusiastic newcomers, and the school began to embark on a variety of new approaches. Two years later the faculty was conducting a needs assessment of its community and crystalizing the results into a new set of curriculum goals. The changes had helped the school to move from twentieth to fourth place in the district in reading achievement test scores. One of the side effects of the changes in both schools was to produce far better opportunities for white students with learning problems.

David Tew, principal of the Longfellow School in Riverside, tells a similar story of a long process of transition. ${ }^{106}$ Longfellow, with a 52 per cent minority enrollment, was plagued with discipline problems and poor morale. It had a pervasive sense of failure and the lowest test scores in the system. At first, Tew spent many hours dealing with complaints and handling "name-calling, fights, racial epithets, filthy language and vandalism." The teachers had struggled with the problems in a variety of ways: some tried "harsh discipline," others used tracking, and some were trying to find ways to use teacher aides effectively.

Tew, who had been working on a non-graded way to teach reading skills, brought with him a small nucleus of three teachers, including a reading specialist. He asked two of the seventeen existing teachers to leave and explained to the rest what he thought needed to be done in changing teaching methods, telling them they should "feel free to ask for a transfer" if they felt uncomfortable.

After some initial anxiety and some departures, things settled down and only a single teacher requested a transfer during the next six years. The teachers began by carefully analyzing the problems of fifth and sixth graders with reading difficulties. The analysis uncovered "many areas that just were not dealt with." For example, it was found that some of the students still lacked the eye-hand coordination necessary to begin reading. In response, new exercises were built into the physical education curriculum. When the Riverside school system implemented decentralized planning and budgeting, the staff of Longfellow became intensely involved in developing a plan for change. The school won a $\$ 10,000$ grant from the district to carry out a special three-year program including systematic development of the new reading and math methods.

106. Interview with David Tew, Principal, Longfellow Elementary School in Riverside, Calif., Oct. $27,1972$. 
The process of shared planning, Tew believes, pulled the members together behind the new program.

The results of the new philosophy and newly implemented programs were dramatic. In the first year after the new methods had been introduced, the school's achievement scores moved from last in the district to the middle level. The next year, the school was first in the district. ${ }^{107}$

At the South San Jose Elementary School in Jacksonville, Florida, Principal Marie Patterson recalls that before the desegregation process took place, there were teachers who had never seen below-average children in the affluent white school. ${ }^{108}$ "We had been," she said, "a little private school in a private community, supported by public funds." Teachers were "fearful that they would not be able to handle the range of abilities." Rapid curriculum change came to this school when parents demanded that the school implement individualized approaches which had been tried out elsewhere in the district. When this was done, a substantial number of the children that had transferred to private schools returned, the number of parents serving as volunteers in the school increased, and the PTA began to raise funds for some necessary equipment.

A school which has successfully been through this long process of adaptation and change often ends up with a program that offers broadened opportunities for all children. In Roanoke, Virginia ${ }^{109}$ a number of elementary and intermediate schools moved to individualized instruction following desegregation of the school system. Interesting changes took place in surprising areas of the curriculum. The staff found, for example, that their policies of concentrating on arts and crafts and choral music at black schools, and classical music and traditional art instruction at the white high schools, had overlooked strong interests which crossed racial lines in both directions. ${ }^{110}$

Principals in those schools which have responded to desegregation with educational reforms report cycles of early fear, then exploration and planning, and finally change. None think that they have a magic formula or one that is

107. A similar story of traumatic initial adjustment, but eventual success-after more than five years-was related by Principal Euta Mae Mosely of the Meadow Park Elementary School in Palm Beach County, Fla., Dec. 4, 1972.

108. Interview with Marie Patterson, Principal of South San Jose Elementary School in Duval County, Fla., Dec. 8, 1972.

109. Interview with Roanoke school system staff members in Roanoke, Va., Oct. 13, 1972. The Virginia State Department of Education, operating in the state that had once led "massive resistance" to token desegregation, acted in the early 1970's to sponsor the development of an integrated curriculum for the VIRGINIA! television series broadcast for state-wide classroom use through the state's instructional television network. Interview with Mary Franklin in Richmond, Va., Sept. 19, 1972. Although this state, in the very recent past, has required the use of the Cavalier Commonwealth text, which had portrayed the happy lot of slaves, a prominent black historian is now playing a major role in constructing the course guide.

110. A similar experience occurred in Greenville, S.C., where school officials found that there was considerable white student interest in auto mechanics and other skilled trade courses that had been offered only in the black schools before integration. Interview with Wayman Burton, Principal, Bryson Ninth Grade Center, in Greenville, S.C., Dec. 13, 1972. The comments of a principal in 
suitable to all teachers or all schools. Most strongly emphasize the importance of faculty involvement in planning, and no one disputes the fact that the transition takes years.

If real desegregation is a long-term process requiring an analysis of basic educational philosophies and a restructuring of the way classrooms operate, this should be considered at the time that the desegregation plan is developed. It is at this point where there can be some leverage on a school system to support the needed long-term changes. Desegregation plans should provide expert assistance, and, if possible, small budgets to support experiments within individual schools to help work out the necessary adjustments. It is also important for teachers and principals who are deeply confused to have a chance to visit schools where desegregated education is working. School principals usually have very little money for new departures once their obligations for salaries, supplies, and fixed costs are met. Targeting even a few thousand dollars for planning, curriculum development, and needed materials can greatly facilitate change. Unfortunately, most existing federal desegregation aid funds are targeted on the immediate period of transition and withdrawn long before the process has run its course. ${ }^{11}$ In too many cases, it has not even begun by the time funds are withdrawn.

\section{Conclusion}

Desegregation raises new educational problems for schools, but it also presents them with a very rare opportunity. Older school systems, especially the large urban systems, are notoriously resistant to reform. Some tend toward the kind of mindless unchanging bureaucracy described in David Rogers' 110 Livingston Street ${ }^{112}$ and other recent books about central city school systems. ${ }^{113}$ Professor Willis Hawley, in his study of organizational rigidity in school systems, attributes much of the system's inability to adapt to changing educational requirements to a rigid centralized bureaucratic structure which strongly reinforces the tendency of schools to perpetuate traditional curricular offerings and teaching methods. ${ }^{114}$ School systems, he reports, tend to impose uniformity on everything from the age placement of students, to texts, to the type of

Little Rock, Ark., also indicate that by offering a stereotyped curriculum, many white students had been disadvantaged.

I've been a principal for 20 years in Little Rock, and my job is far more difficult-but far more interesting - than before integration. I think we neglected lower-level youngsters in our all-white schools before, and it took integration to show the need for an expanded curriculum.

J. Peppler, Little Rock 17 Years After 10 (1974).

111. See, e.g., Emergency School Aid Act, 20 U.S.C.A. $\$ 1601-19$ (1974); Civil Rights Act of

1964, Titles IV \& V, 42 U.S.C. $\$ \S 2000 d \& 2000 \mathrm{e}(1970)$.

112. D. Rogers, 110 Livingston Street (1968).

113. See, e.g., M. Gittell, Participants \& Participation (1967).

114. W. Hawley, Dealing with Organizational Rigidity in Public Schools: A Theoretical Perspective, Fall 1974 (unpublished paper delivered at the 1974 annual meeting of the American Political Science Association). 
person selected as a teacher. Their desire for stability and uniformity thus causes resistance to change that may well require several decades for the general adoption of major innovations. Naturally enough, this rigid structure strongly discourages creativity by teachers. Thus, "special opportunities" for change come with crisis situations: ${ }^{115}$

At critical points in all crises the climate is right for a major innovation. If it is the right proposal for the right time and people, substantial progress can be made in the system. The reason may be that as strain continues, most parties io the strife are anxious for a plausible solution.

The advent of desegregation is such a crisis for many teachers and administrators. It can also be the opportunity for the initiation of very important educational reforms in circumstances where reforms are normally very difficult. To the extent possible, litigants, judges, and planners within school systems should attempt to devise plans which recognize that physical desegregation is only the first step toward social and educational adaptation of the schools. Court should draw on the broad equitable power they possess to remedy segregation by requiring local school officials to prepare a long-term educational plan to make desegregation work educationally and help turn physically desegregated schools into genuinely integrated schools. Even in cases where the local school officials adamantly oppose preparation of the plan for physical desegregation, they should be ordered to devise a supporting program of educational change. The plans should respect the individual school as an important institution faced with a major challenge and should attempt to aid principals and teachers in working out better ways to meet the diverse needs of students within a context of successful integration.

115. Outside of the "special opportunities" provided by crisis situations, educational innovations have generally been adopted less frequently in the area where the need for them is most urgent-1he ghettos and central city schools-than where they are least needed-the suburbs. One recent study of innovation, for example, concluded that communities with higher economic status. educational levels. and staff exposure to ideas from outside the system were more likely to be receptive to change. Hearn. The Where, When and How of Trying Innovations, 53 PHi Delta KappaN 358-61, 374 (1972). The Ford Foundation's evaluation of its educational reform experiments of the 1960's produced a similar finding about the tendency of suburban systems to be far more responsive to new methods, see P. Nachtigal. A Fousdation Gors to School 18 (1972). 